\title{
Knowledge and Risk Perception of COVID-19 and the Willingness to Take COVID-19 Vaccine among Tertiary Institution Students in Jos, Plateau State: a Comparative Assessment of Medical and Nursing Students
}

\author{
Agbo HA ${ }^{1}$, Noel NB ${ }^{2}$, Nkala $\mathrm{CA}^{2}$, Mamza $\mathrm{JJ}^{2}$, Balogun $\mathrm{RO}^{2}$ \\ ${ }^{1}$ Department of Community Health, College of Health Sciences, University of Jos, Jos, \\ Plateau State \\ ${ }^{2}$ Department of Community Medicine, Jos University Teaching Hospital, Jos, Plateau \\ State \\ Corresponding Author:dragboha@yahoo.com,+2348034521494
}

\begin{abstract}
Background: Coronavirus disease has assumed increasing public health importance globally, especially in terms of its impact on the health systems and economies. Despite the abundance of information on COVID-19 in the public domain, misinformation is rife and the uptake of COVID-19 vaccine is tainted by controversies and cynicisms. This study compared the knowledge and risk perception of COVID-19 between medical and nursing students in Jos and their willingness to take the vaccine.
\end{abstract}

Methods: This was a comparative cross-sectional study among 186 medical and 129 nursing students in Jos selected through a stratified sampling technique. Data was collected through a semi-structured selfadministered questionnaire and analyzed using the Statistical Package for Social Sciences version 23. A p-value of $\leq 0.05$ was considered statistically significant.

Results: Medical students had significantly better knowledge $(55.4 \% \mathrm{vs}$ $5.4 \%$ ) and risk perception (93.5\% vs 47.3\%) of COVID-19 compared to the nursing students ( 0.0001). One hiundred and fifity seven respondents (71.1\%) were vaccine-hesitant and this was worse in the nursing students $(82.9 \%)$ than in the medical students $(62.9 \%)$. Lack of trust for a COVID19 vaccine bothering on its efficacy, safety profile, adverse effects, and rapidity of development and testing were the leading reasons for vaccine hesitancy.

Conclusion: Medical students had better knowledge and perception of COVID-19 risk than their nursing counterparts. COVID-19 vaccine hesitancy is high among medical and nursing students. Therefore, further education by school authorities on COVID-19 and the role of vaccines in its control is necessary.

Keywords: COVID-19; Knowledge; Medical and nursing students; Risk perception; Vaccine; 


\section{Introduction}

Coronavirus Disease (COVID-19) was first discovered in Wuhan, China in 2019 and has now become a disease of global public health concern infecting over 188 million persons with over 4 million deaths. It has adversely affected the health systems of several nations especially those in resource-limited settings, ${ }^{2}$ and has significantly crippled economic activities chiefly due to lockdowns and travel restrictions to curtail its spread resulting in low economic output, thereby throwing nearly half of the over 3 billion global workforce into job losses or at the brink of job losses; decreased household incomes with increasing cost of healthcare, and a diminished access to antenatal, immunization, tuberculosis, HIV services. ${ }^{4}$

Recent development shows that vaccination against COVID-19 is an essential element of the fight against the pandemic. Therefore, it will be expected that if vaccines are promptly made widely available the population will be protected against new variants. ${ }^{5}$ Different vaccines have been rolled out for use in different countries; which includes OxfordAstraZeneca, Pfizer-Biontech, Moderna/NIAID, Johnson and Johnson, etc. $^{6}$ The first global mass vaccination campaign began in December 2020 initially administered mostly to individuals considered to be high risks such as health workers and older people. ${ }^{7}$

Despite the high-risk profile of healthcare workers (HCWs) and students in medical practice, a significant proportion has a wrong perception of their risk for the disease which could explain why a great number of them have shown unwillingness to take COVID-19 vaccines. Hesitancy towards taking COVID-19 vaccines has mostly been attributed to many reasons and $\mathrm{HCW}$ s equally have a mistrust for the information related to vaccine development and safety emanating from government officials and public health experts and a lack of confidence and transparency in the process. ${ }^{8-11}$ The HCWs globally are at the highest risk of infection, ${ }^{12,}{ }^{13}$ with worldwide recorded deaths ${ }^{14}$ due to contact exposure and susceptibility to infection. ${ }^{15-17}$ Other reasons are lack of PPE, inadequacy of safety procedures and policies in the workplace, little/no support from management when they fall sick and lack of adequate knowledge of COVID-19. ${ }^{17-20}$ Ironically, up to $10 \%$ of students in medical courses have been infected with COVID-19. ${ }^{21}$

Although a significant proportion of HCWs and students have correctly perceived themselves to be at risk of coronavirus virus infection, ${ }^{10,20}$ about $20 \%$ think the disease is not fatal, $61 \%$ do not know its mode of transmission and incubation period. ${ }^{22}$ Students of medical and allied health institutions occupy a key position of influence in the society and play a vital role in the health system and, by the nature of their training, they could be consulted for medical assistance and information on the disease. Yet about $70 \%$ of HCWs and between $23 \%$ to $55 \%$ of students in medical institutions expressed unwillingness to get vaccinated with COVID-19 vaccines. ${ }^{9-11}$ Most studies on risk perception and readiness to accept COVID-19 vaccines have focused on $\mathrm{HCW}$ with little interest in medical students who oftentimes may have similar risks as their trainers. This explains the paucity of evidence on the topic among medical students. Therefore, this study attempted to fill this gap in this locality and possibly provide a baseline upon which interventions targeting the subject matter will be evaluated by assessing the knowledge, risk perception of COVID-19 
and the willingness of tertiary institution students to take the vaccines comparing the medical and nursing students in Jos, Plateau State.

\section{Methods}

\section{Study area, population and design}

The study was carried out at the University of Jos and the Plateau State College of Nursing Jos, both located in the Jos metropolis. The University of Jos is a federal tertiary institution in the State having over 40,000 students. ${ }^{24}$ The Plateau State College of Nursing Jos is a Stateowned institution with about 250 basic nursing students. The study used a comparative cross-sectional study design with a population of clinical medical students (400-600level) of the University of Jos and nursing students (year 1-3) of the Plateau State College of Nursing, Jos. Pre-clinical medical students $(100-300$ level) were excluded from the study because they were not in session. The minimum sample size was determined using the formula ${ }^{25}$

$\mathrm{n}=\frac{\left(\mathrm{Z}_{\alpha}^{2}+\mathrm{Z}_{\beta}\right) \times 2 \times \mathrm{P}(1-\mathrm{P})}{\mathrm{d}^{2}}$

where: $\mathrm{n}=$ minimum sample size per group $\mathrm{Z} \alpha=$ standard normal deviate at $95 \%$ confidence interval $=1.96$

$\mathrm{Z}_{\beta}=$ standard normal deviate at a power of $80 \%=0.84$

$\mathrm{P}_{1}=$ proportion of medical students willing to accept COVID-19 vaccine from a previous study $=82.7 \%(0.827){ }^{26}$

$\mathrm{P}_{2}=$ proportion of nursing students willing to accept COVID-19 vaccine from a previous study $=83.2 \%(0.832){ }^{26}$

$\mathrm{P}=\left(\mathrm{P}_{1}+\mathrm{P}_{2}\right) / 2=82.95 \%(0.8295)$

$1-\mathrm{P}=$ Complimenary probability $=1$ $0.8295=0.1705$

$\mathrm{d}=$ difference to be detected $=10 \%(0.1)$ $\mathrm{n}=(1.96+0.84)^{2} \times 2 \times 0.8295(0.1705)=$

$$
0.1^{2} \quad \frac{2.2176}{0.01} \approx 222
$$

With assumption of $10 \%$ non-response rate (r) the calculated minimum sample size was adjusted using the formula $=\frac{\mathrm{n}}{1-\mathrm{r}}=\frac{222}{1-0.10} \approx 247$ per group.

\section{Sampling technique, data collection and analysis}

A three-staged method was used to sample the study population. First, the University of Jos and Plateau State School of Nursing were purposively selected. Then the medical and nursing students were stratified into two strata (males \& females) in all the levels selected. Thus the 400-600 level medical and 100-300 level nursing students were allotted class number based on each stratum (e.g. for the male, total number of males [a] /total population of the students [b] * sample size [y]).

Stage Three: The sample size [y] for each calculated stata was proportionately allotted based on the number of each gender in each selected level [x] by the total number in all the levels [z] i.e. $\left(\mathrm{x} / \mathrm{z}^{*} \mathrm{y}\right)$. using the class representatives, consented students balloted an assigned class number based on strata until the required number were obtained.

Data was collected using a semi-structured self-administered questionnaire. The questionnaire contained five sections; socio-demographic characteristics, knowledge of COVID-19, perception of COVID-19 risk, intention to accept COVID-19 vaccine, and reasons for not wanting to take COVID-19. From the data collected, the responses were coded and entered into a spreadsheet in Microsoft excel software and subsequently cleaned. Thereafter, the data was exported to IBM Statistical Package for the Social Sciences (SPSS) version 23 for analysis. Sociodemographic characteristics were expressed as frequencies and percentages. Knowledge had 26 scores; correct answers scored 1, incorrect answers and non- 
response scored 0 . Total knowledge score of $\geq 70 \%$ was rated as good knowledge, $<70 \%$ was rated as poor knowledge considering the study population in question.

Assessing risk perception, 5 points Likert response were scored: 5 strongly agree, 4 agree, 3 not sure, 2 disagree and 1 strongly disagree. A score of $\geq 70 \%$ was classified as high while $<70 \%$ was classified as low perception of risk. Question on willingness to accept a COVID-19 vaccine was "when the COVID-19 vaccine becomes available to you, are you willing to take it?" All "Yes" responses were categorized as willing to take the vaccine while "Not sure" or "No" were categorized as vaccinehesitant. Multivariable logistic regression was used to examine associations between the socio-demographic variables, knowledge and risk perception and willingness to accept COVID-19 vaccine. Adjusted odds ratios (aORs) were used to express the strength of the associations and statistical significance was determined at an alpha level of $\mathrm{p} \leq 0.05$.

\section{Ethical consideration}

Written consent was obtained from the study participants after a detailed explanation of the nature of the research before the commencement of the research and participation was voluntary. In addition, absolute confidentiality of the data was maintained.

\section{Results}

The mean ages were $26.4 \pm 3.8$ years and $22.2 \pm 3.9$ years for medical and nursing students respectively. Majority were males $(51.4 \%)$ and in the second year of their training;500 level (53\%). One hundred and fourteen $(36.2 \%)$ had a training or continuing education on COVID-19, $63(20 \%)$ had had contact with a suspected/confirmed case of COVID-19 and $28(8.9 \%)$ had a pre-existing medical condition (Table 1).

Overall, $138(43.8 \%)$ rated their knowledge of COVID-19 to be good. Knowledge of COVID-19 revealed that $110(34.9 \%)$ had a good level of knowledge. Specifically, 55.4\% of medical students and $5.4 \%$ of nursing students had good knowledge and the difference in knowledge between them was statistically significant $\left(\mathrm{p}^{<} 0.0001\right)$. Majority of the medical (93.5\%) and nursing; 61(47.3\%) students perceived their risk to be high but the difference in risk perception between the two groups was statistically significant $\left(p^{<} 0.0001\right)$. Only 91(28.9\%) respondents expressed a willingness to take a COVID19 vaccine; $37.1 \%$ medical students compared to $17.1 \%$ nursing students (Table 2).

In Table 3, $219(97.8 \%)$ out of the 224 vaccine-hesitant respondents indicated one or more reasons for their unwillingness to take a COVID-19 vaccine. The most common concern was about the efficacy of the vaccine and not being convinced it will be effective $(71.7 \%)$. Other leading reasons were concerns about the safety profile and adverse effects $(66.7 \%)$, concerns about the hurried vaccine production $(57.5 \%)$ and lack of trust for vaccines produced for COVID-19(53.4\%).

On logistic regression, medical students who were in higher levels of study (500 and 600 levels), and those who had had no clinical rotation in the year preceding this study were at least three times more likely to be willing to take a COVID-19 vaccine compared to those in 400 level and those who had had a clinical rotation in the past year. Medical students who were females and those older than 24 years were less likely to indicate a willingness to take a COVID-19 vaccine compared to the males and those aged 24 years or less. Knowledge, perception of risk, 
training/continuing education on COVID19 , and history of contact with a suspected or confirmed case of COVID-19 were not statistically significant predictors of the willingness to take a COVID-19 vaccine. However, for the nursing students, while belonging to the age-group 25-33 years significantly increased the odds of the

\section{Tables}

Table 1: Socio-demographic characteristics of the respondents $(n=315)$

\begin{tabular}{|c|c|c|c|c|c|c|}
\hline Variable & $\begin{array}{c}\text { MBBS in View } \\
(\mathbf{n}=186) \\
\mathbf{f}(\%)\end{array}$ & $\begin{array}{c}\text { Nursing in View } \\
(\mathrm{n}=129) \\
\mathbf{f}(\%)\end{array}$ & $\begin{array}{c}\text { Total } \\
(\mathbf{n}=\mathbf{3 1 5}) \\
\mathbf{f}(\%)\end{array}$ & $?^{2}$ & df & $\overline{p \text {-value }}$ \\
\hline \multicolumn{7}{|l|}{ Age group (years) } \\
\hline $16-24$ & $64(34.4)$ & $101(78.3)$ & $165(52.4)$ & 58.823 & 2 & ? 0.0001 \\
\hline $25-33$ & $114(61.3)$ & $26(20.2)$ & $140(44.4)$ & & & \\
\hline $34-42$ & $8(4.3)$ & $2(1.6)$ & $10(3.2)$ & & & \\
\hline Mean age (years) & $26.4 \pm 3.8$ & $22.2 \pm 3.9$ & & $9.559^{\#}$ & 313 & ? 0.0001 \\
\hline \multicolumn{7}{|l|}{ Sex } \\
\hline Male & $114(61.3)$ & $48(37.2)$ & $162(51.4)$ & 17.683 & 1 & ? 0.0001 \\
\hline Female & $72(38.7)$ & $81(62.8)$ & $153(48.6)$ & & & \\
\hline \multicolumn{7}{|l|}{ Level of study } \\
\hline Year 1/400L & $31(16.7)$ & $38(29.5)$ & $69(21.9)$ & 10.826 & 2 & 0.004 \\
\hline Year 2/500L & $112(60.2)$ & $55(42.6)$ & $167(53.0)$ & & & \\
\hline Year 3/600L & $43(23.1)$ & $36(27.9)$ & $79(25.1)$ & & & \\
\hline \multicolumn{7}{|l|}{ Ethnicity } \\
\hline Plateau Indigenous & $58(31.2)$ & $92(71.3)$ & $150(47.6)$ & 65.199 & 5 & ? 0.0001 \\
\hline Hausa & $10(5.4)$ & $11(8.5)$ & $21(6.7)$ & & & \\
\hline Igbo & $37(19.9)$ & $8(6.2)$ & $45(14.3)$ & & & \\
\hline Yoruba & $17(9.1)$ & $10(7.8)$ & $27(8.6)$ & & & \\
\hline Idoma & $22(11.8)$ & $0(0.0)$ & $22(7.0)$ & & & \\
\hline Others & $42(22.6)$ & $8(6.2)$ & $50(15.9)$ & & & \\
\hline \multicolumn{7}{|l|}{ Religion } \\
\hline Christianity & $173(93.0)$ & $116(89.9)$ & $289(91.7)$ & $2.371^{+}$ & 2 & 0.306 \\
\hline Islam & $12(6.5)$ & $13(10.1)$ & $25(7.9)$ & & & \\
\hline Agnostic & $1(0.5)$ & $0(0.0)$ & $1(0.3)$ & & & \\
\hline \multicolumn{7}{|l|}{$\begin{array}{l}\text { Pre-existing medical } \\
\text { condition }\end{array}$} \\
\hline No & $178(95.7)$ & $109(84.5)$ & $287(91.1)$ & 11.804 & 1 & 0.001 \\
\hline Yes & $8(4.3)$ & $20(15.5)$ & $28(8.9)$ & & & \\
\hline \multicolumn{7}{|l|}{ Contact with } \\
\hline \multirow{2}{*}{\multicolumn{7}{|c|}{$\begin{array}{l}\text { suspected/confirmed case } \\
\text { Yes }\end{array}$}} \\
\hline & & & & & & \\
\hline \multirow[t]{2}{*}{ No } & $55(29.6)$ & $8(6.2)$ & $63(20.0)$ & 25.997 & 1 & ? 0.0001 \\
\hline & $131(70.4)$ & $121(93.8)$ & $252(80.0)$ & & & \\
\hline \multicolumn{7}{|c|}{ Ever tested for COVID } \\
\hline Yes & $18(9.7)$ & $17(13.2)$ & $35(11.1)$ & 0.945 & 1 & 0.331 \\
\hline No & $168(90.3)$ & $112(86.8)$ & $280(88.9)$ & & & \\
\hline \multicolumn{7}{|c|}{$\begin{array}{l}\text { Outcome of COVID test } \\
(n=35)\end{array}$} \\
\hline Positive & $9(50.0)$ & $3(17.6)$ & $12(34.3)$ & 4.062 & 1 & 0.044 \\
\hline Negative & $9(50.0)$ & $14(82.4)$ & $23(65.7)$ & & & \\
\hline \multicolumn{7}{|c|}{$\begin{array}{l}\text { Training/continuing } \\
\text { education on COVID }\end{array}$} \\
\hline Yes & $82(44.1)$ & $32(24.8)$ & $114(36.2)$ & 12.261 & 1 & ? 0.0001 \\
\hline No & $104(55.9)$ & $97(75.2)$ & $201(63.8)$ & & & \\
\hline
\end{tabular}

willingness to take a COVID-19 vaccine compared to those aged 16-24 years, the likelihood of the willingness to receive COVID-19 vaccine was decreased for those who rated their risk of contracting COVID-19 to be either medium or low compared to those rating theirs to be high. 
Table 2: Knowledge, risk perception and willingness to take COVID vaccine amongst respondents.

\begin{tabular}{|c|c|c|c|c|c|c|}
\hline Variable & $\begin{array}{c}\text { Medicine } \\
(n=186) \\
\mathbf{f}(\%)\end{array}$ & $\begin{array}{c}\text { Nursing } \\
(n=129) \\
f(\%)\end{array}$ & $\begin{array}{c}\text { Total } \\
(\mathbf{n}=315) \\
\mathbf{f}(\%) \\
\end{array}$ & $?^{2}$ & df & p-value \\
\hline \multicolumn{7}{|c|}{$\begin{array}{l}\text { Self-rated knowledge of } \\
\text { COVID-19 }\end{array}$} \\
\hline Good & $95(51.1)$ & $43(33.3)$ & $138(43.8)$ & $9.709^{+}$ & 1 & $0.002^{*}$ \\
\hline Poor & $91(48.9)$ & $86(66.7)$ & $177(56.2)$ & & & \\
\hline $\begin{array}{l}\text { Assessed knowled } \\
\text { COVID-19 }\end{array}$ & \multicolumn{3}{|c|}{ Assessed knowledge of } & 83.625 & 1 & ? $0.0001^{*}$ \\
\hline $\begin{array}{l}\text { Good } \\
\text { Poor }\end{array}$ & \multicolumn{5}{|c|}{ Poor } & \\
\hline \multicolumn{7}{|c|}{$\begin{array}{l}\text { Self-rated risk of } \\
\text { contracting COVID-19 }\end{array}$} \\
\hline High & $79(42.5)$ & $23(17.8)$ & $102(32.4)$ & 22.627 & 2 & ? $0.0001^{*}$ \\
\hline Medium & $75(40.3)$ & $82(63.6)$ & $157(49.8)$ & & & \\
\hline Low & $32(17.2)$ & $24(18.6)$ & $56(17.8)$ & & & \\
\hline \multicolumn{7}{|c|}{$\begin{array}{l}\text { Perception of COVID -19 } \\
\text { risk }\end{array}$} \\
\hline High & $174(93.5)$ & $61(47.3)$ & $235(74.5)$ & 86.039 & 1 & ? $0.0001^{*}$ \\
\hline Low & $12(6.5)$ & $68(52.7)$ & $80(25.4)$ & & & \\
\hline \multicolumn{7}{|c|}{$\begin{array}{l}\text { Feel adequately } \\
\text { protected during } \\
\text { rotations in the wards }\end{array}$} \\
\hline Strongly Agree & $13(7.0)$ & $18(13.9)$ & $31(9.8)$ & 65.917 & 4 & ? $0.0001^{*}$ \\
\hline Agree & $30(16.1)$ & $57(44.2)$ & $87(27.6)$ & & & \\
\hline Not Sure & $48(25.8)$ & $42(32.6)$ & $90(28.6)$ & & & \\
\hline Disagree & $48(25.8)$ & $7(5.4)$ & $55(17.5)$ & & & \\
\hline Strongly Disagree & $47(25.3)$ & $5(3.9)$ & $52(16.5)$ & & & \\
\hline \multicolumn{7}{|c|}{$\begin{array}{l}\text { Willingness to accept } \\
\text { COVID vaccine }\end{array}$} \\
\hline Yes & $69(37.1)$ & $22(17.1)$ & $91(28.9)$ & 14.895 & 1 & ? $0.0001^{*}$ \\
\hline No & $117(62.9)$ & $107(82.9)$ & $224(71.1)$ & & & \\
\hline
\end{tabular}

Likelihood ratio chi-square

"Statistically significant 
Table 3: Factors militating against the willingness to take a COVID-19 vaccine $(n=219)$.

\begin{tabular}{lccc}
\hline \multicolumn{1}{c}{ Reasons } & Frequency & $\mathbf{\%}$ \\
\hline 1. Concerns about the efficacy of the vaccine/not convin ced it will be & 157 & 71.7 \\
effective & 146 & 66.7 \\
2. Concerns about the safety profile and side effects of the vaccine & 126 & 57.5 \\
3. Concerns about how fast the vaccine development and testing was & & \\
$\quad \begin{array}{l}\text { carried out/approval was too quickly because of political pressure } \\
\text { 4. Lack of trust for any vaccine made for COVID -19 }\end{array}$ & 117 & 53.4 \\
5. Lack of trust for the information coming from the government and & 101 & 46.2 \\
public health experts on COVID -19 and its vaccine & & \\
6. Don't feel at risk of getting COVID -19 & 44 & 38.4 \\
7. The magnitude of the pandem ic in Nigeria is not serious enough & 48 & 21.9 \\
8. The vaccine will not protect me against the disease & 44 & 20.1 \\
9. The vaccine might transmit the virus & 27 & 19.6 \\
10. My immune system is weak/have an allergy to many substances & & \\
$\quad$ and may have an allergy to this vaccine & \\
\hline
\end{tabular}


Table 4a: Predictors of willingness to take a COVID-19 vaccine amongst the respondents

\begin{tabular}{|c|c|c|c|c|}
\hline \multirow[t]{2}{*}{ Variable } & \multicolumn{2}{|c|}{ Medicine } & \multicolumn{2}{|c|}{ Nursing } \\
\hline & aOR $(95 \% \mathrm{CI})$ & p-value & aOR $(95 \% \mathrm{CI})$ & p-value \\
\hline \multicolumn{5}{|l|}{ Age group (years) } \\
\hline $16-24$ & 1 & & 1 & \\
\hline $25-33$ & $0.38(0.16-0.92)$ & $0.031^{*}$ & $10.26(2.16-48.70)$ & $0.003^{*}$ \\
\hline $34-42$ & $0.07(0.01-0.74)$ & $0.027^{*}$ & $0.06(0.00-70658)$ & 0.689 \\
\hline \multicolumn{5}{|l|}{ Sex } \\
\hline Male & 1 & & 1 & \\
\hline Female & $0.37(0.16-0.85)$ & $0.020^{*}$ & $0.39(0.06-2.72)$ & 0.344 \\
\hline \multicolumn{5}{|l|}{ Level of study } \\
\hline 400L/Year 1 & 1 & & & \\
\hline $500 \mathrm{~L} /$ Year 2 & $3.34(1.16-9.63)$ & $0.025^{*}$ & $1.32(0.14-12.29)$ & 0.806 \\
\hline $600 \mathrm{~L} /$ Year 3 & $3.61(1.02-12.80)$ & $0.047^{*}$ & $0.44(0.06-3.14)$ & 0.415 \\
\hline \multicolumn{5}{|l|}{ Ethnicity } \\
\hline Plateau indigenous & 1 & & 1 & \\
\hline Hausa & $0.41(0.08-2.12)$ & 0.285 & $0.00(0.00-8)$ & 0.999 \\
\hline Igbo & $0.43(0.15-1.23)$ & 0.116 & $1.33(0.04-44.28)$ & 0.872 \\
\hline Yoruba & $0.72(0.20-2.67)$ & 0.625 & $0.84(0.05-14.59)$ & 0.907 \\
\hline Idoma & $0.47(0.14-1.59)$ & 0.223 & - & - \\
\hline Others & $0.61(0.24-1.57)$ & 0.307 & $0.00(0.00-8)$ & 0.999 \\
\hline \multicolumn{5}{|l|}{ Religion } \\
\hline Christianity & 1 & & 1 & \\
\hline Islam & $4.29(0.89-20.58)$ & 0.069 & $0.46(0.01-49.00)$ & 0.745 \\
\hline Agnostic & $0.56(0.00-8)$ & 1.000 & - & \\
\hline \multicolumn{5}{|c|}{$\begin{array}{l}\text { Pre-existing medical } \\
\text { condition }\end{array}$} \\
\hline No & 1 & & 1 & \\
\hline Yes & $0.00(0.00-8)$ & 0.999 & $1.22(0.08-19.43)$ & 0.890 \\
\hline \multicolumn{5}{|c|}{$\begin{array}{l}\text { Clinical rotations in } \\
\text { the past year }\end{array}$} \\
\hline Yes & 1 & & 1 & \\
\hline No & $3.59(1.34-9.58)$ & $0.011^{*}$ & $0.20(0.01-2.99)$ & 0.241 \\
\hline \multicolumn{5}{|c|}{$\begin{array}{l}\text { Contact with } \\
\text { suspected/confirmed } \\
\text { case }\end{array}$} \\
\hline Yes & 1 & & 1 & \\
\hline No & $0.98(0.42-2.30)$ & 0.961 & $4.72(0.05-496.20)$ & 0.514 \\
\hline \multicolumn{5}{|c|}{$\begin{array}{l}\text { Training/Continuing } \\
\text { education on COVID }\end{array}$} \\
\hline Yes & 1 & & 1 & \\
\hline No & $0.99(0.49-1.99)$ & 0.971 & $0.51(0.09-2.91)$ & 0.450 \\
\hline \multicolumn{5}{|c|}{$\begin{array}{l}\text { Self-rated knowledge } \\
\text { of COVID }\end{array}$} \\
\hline Good & 1 & & 1 & \\
\hline Average & $0.94(0.46-1.91)$ & 0.854 & $0.41(0.09-1.84)$ & 0.245 \\
\hline Poor & $0.00(0.00-8)$ & 0.999 & $0.00(0.00-8)$ & 0.999 \\
\hline
\end{tabular}

"Statistically significant 
Table 4b: Predictors of willingness to take a COVID-19 vaccine amongst the respondents

\begin{tabular}{|c|c|c|c|c|}
\hline \multirow[t]{2}{*}{ Variable } & \multicolumn{2}{|c|}{ Medicine } & \multicolumn{2}{|c|}{ Nursing } \\
\hline & $\operatorname{aOR}(95 \% \mathrm{CI})$ & p-value & aOR $(95 \% \mathrm{CI})$ & p-value \\
\hline \multicolumn{5}{|l|}{$\begin{array}{l}\text { Assessed knowledge of } \\
\text { COVID }\end{array}$} \\
\hline Poor & 1 & & 1 & \\
\hline Good & $1.28(0.60-2.73)$ & 0.529 & $5.43(0.06-478.19)$ & 0.459 \\
\hline \multicolumn{5}{|l|}{$\begin{array}{l}\text { Self-rated risk of } \\
\text { contracting COVID }\end{array}$} \\
\hline High & 1 & & 1 & \\
\hline Medium & $0.85(0.38-1.93)$ & 0.699 & $0.02(0.01-0.52)$ & $0.017^{*}$ \\
\hline Low & $0.44(0.13-1.47)$ & 0.181 & $0.03(0.01-0.89)$ & $0.043^{*}$ \\
\hline \multicolumn{5}{|l|}{$\begin{array}{l}\text { Perceived risk of } \\
\text { COVID }\end{array}$} \\
\hline Low & 1 & & 1 & \\
\hline High & $7.70(0.79-75.62)$ & 0.080 & $0.13(0.01-1.56)$ & 0.106 \\
\hline \multicolumn{5}{|l|}{$\begin{array}{l}\text { Feel adequately } \\
\text { protected during } \\
\text { rotations in the wards }\end{array}$} \\
\hline Strongly agree/Agree & 1 & & 1 & \\
\hline Not sure & $0.98(0.34-2.84)$ & 0.967 & $5.62(0.81-38.86)$ & 0.080 \\
\hline $\begin{array}{l}\text { Strongly } \\
\text { disagree/Disagree }\end{array}$ & $0.90(0.35-2.35)$ & 0.833 & $2.00(0.18-22.70)$ & 0.576 \\
\hline
\end{tabular}

"Statistically significant

\section{Discussion}

Medical and nursing students can be termed as role models to other students; they may be observed for health behaviours and asked questions on health matters. The knowledge assessed brought to limelight gaps about the disease even among the to-be doctors and nurses. Good knowledge of COVID-19 is sinequanon for staying healthy by ensuring compliance to public health preventive measures. ${ }^{27}$ Although the majority of the respondents rated their knowledge of COVID-19 as good, objective assessment of their knowledge revealed that overall only about a third of them had a good level of knowledge. Precisely, there was a significant difference in the levels of knowledge between the two groups; the medical students had better knowledge which lectures, ward rounds, clerking of patients may have contributed. Conversely, similar studies, although internet-based, revealed very high levels of COVID-19 knowledge among nursing and medical students. ${ }^{28-31}$ The generally poor knowledge in this study may be attributable to the fact that only about a third of the respondents have been exposed to training or continuing education on COVID-19. However, the discrepancy between self-rated knowledge and assessed knowledge in this study implies that inaccurate information may be rife among the respondents and therefore the knowledge they believe to possess may be largely incorrect. Consequently, patients and other individuals who come into contact with these future healthcare frontlines may benefit little or nothing concerning knowledge building on COVID-19. These students are expected to be sources of accurate health information and, since communication campaigns and training have been identified as ways of combating misinformation and improving knowledge, ${ }^{28,32}$ there is a need for these future healthcare providers to be 
continually exposed to trainings and continuing education concerning emerging disease threats as the need arises.

In general, a large proportion of the respondents had a high perception of their COVID-19 risk, a finding that is expected of this group who, by their training, may likely encounter patients presenting symptoms suggestive of coronavirus infection. However, whereas nearly all the medical students had a high level of risk perception, less than half of the nursing students fell into this category, a difference that is statistically significant. The higher level of knowledge, exposure to COVID19 training and continuing education, clinical rotations in the preceding year, contact with a suspected or confirmed case among the medical students may be responsible for the observed difference. In agreement, a similar study among medical students in Saudi Arabia reported the majority having a high level of risk perception. ${ }^{31}$ Conversely, less than half of the healthcare workers in a study in a tertiary hospital in Nigeria were found to perceive their risk of coronavirus infection to be high. ${ }^{33}$ A high health-related risk perception is an essential contributing factor to health behaviour change and sustaining positive health behaviour. ${ }^{34}$ Believing oneself to be at a lower risk for health outcomes than is reasonable which is similar to what was obtainable among the majority of the nursing students in this study, results in "unrealistic optimism". "Unrealistic optimism" is capable of culminating in less impetus to observe and practice health-protective behaviours and as a result accentuating the risks of adverse health outcomes. ${ }^{34}$

Despite the urgent need to achieve herd immunity against COVID-19 among populations worldwide through high coverage of vaccination campaigns to curtail the spread of the virus, nearly three out of every four respondents in this study were hesitant, outrightly unwilling or unsure of their willingness to take a COVID-19 vaccine. This finding is not at par with the fact that the majority of the respondents didn't rate their risk of contracting COVID-19 as low. Although in both groups far below half of the respondents were willing to take a COVID-19 vaccine, the proportion of medical students willing to accept a vaccine was significantly higher than the nursing students. While a similar study among undergraduate nursing students in the US also found a low willingness to receive a COVID-19 vaccine, ${ }^{35}$ contrasting findings have been reported in other similar studies among medical and nursing students in the US and Poland where the majority were willing to take a COVID-19 vaccine. ${ }^{10,}{ }^{36}$ In the current study it is pertinent to note that a high disease-risk perception has not translated into a high willingness to receive a vaccine. This may be attributable to misinformation among the respondents as demonstrated by the majority of them possessing a poor knowledge of coronavirus. The consequence is the likelihood that this important group of future frontline health workforce may not promote vaccine uptake and its potential benefits in their spheres of influence which include patients.

Commonest reasons for vaccine hesitancy were concerns about the efficacy of the vaccine and not being convinced it will be effective, the safety profile and potential adverse effects of the vaccine, the rapidity of vaccine development, testing and approval hinged on political pressure, and the lack of trust for COVID-19 vaccines. This finding was in agreement with what was reported in other similar studies. . $^{10,35,36}$ The reasons put forward for vaccine- 
hesitancy in this study provide health education and behaviour change opportunities that can address misinformation and myths about the vaccine and COVID-19 in general. They can serve as thematic areas when planning and implementing an intervention.

Among medical students, the predictors of the willingness to take a COVID-19 vaccine were younger age, male sex, higher levels of study, no clinical rotations in the preceding year. For the nursing students, however, older age and a high self-rated risk of contracting COVID-19 were the predictors of the willingness to accept a vaccine. The male sex has been described to be adventurous, risk-prone and open to abstract and new ideas which may include vaccines for a novel disease such as COVID-19. ${ }^{37}$ Nevertheless, it is challenging to come up with a plausible explanation for the association between both younger and older ages, and not being exposed to clinical rotations with vaccine acceptance. There may be some unknown confounders not enumerated in the current study which might underlie and explain this association. Additionally, the generally low vaccine acceptance especially among the nursing students might have masked any statistically significant differences in vaccine acceptance between the sociodemographic, knowledge and risk perception strata. Similar studies among medical students in Egypt and the US have also found higher levels of study and younger age respectively to be predictors of COVID-19 vaccine acceptance, but in addition, other predictors found in these studies included good self perception of one's health status, good self rated COVID 19 knowledge level, presence of confirmed COVID 19 infection in close social network, trust for COVID 19 information received from public health experts, believing that COVID 19 vaccination should be made mandatory for the general public, and not showing concern about serious vaccine side effects. ${ }^{26,38}$ The findings from this study underscore the need for continued and improved dissemination of sound and accurate information on coronavirus inclusive of the vaccines to the general public especially medical and nursing students, a large proportion of whom have been found to have inadequate knowledge on COVID-19 and are hesitant towards receiving a vaccine for the disease.

\section{Conclusion}

Despite medical and nursing students' involvement in patients care, the willingness to receive a COVID-19 vaccine was low in both groups with medical students being more willing to recive the vaccine. More so, medical students had a better knowledge of COVID-19 and a higher perception of COVID-19 risk. In both groups, there was a significant gap between self-rated knowledge and assessed knowledge of COVID-19. Therefore it is recommended that school authorities should educate students more on COVID-19 and the role of vaccines in disease control through periodic updates as the need arises to dispel and correct misinformation, increase knowledge, and change the attitude towards public health interventions such as vaccines.

\section{References}

1. World Health Organization. Global situation [Internet]. WHO Coronavirus Disease (COVID-19) Dashboard. 2021 [cited 2021 Feb 28]. A va i a b l e fro m : https://covid19.who.int/?gclid=Cjw KCAiAm 2BBhANEiwAe7eyFEhKMIDXYZ7 MgIs6OSJcs4fYioe0SJYbDjtrVSDD 
uiz3N8CPLJp38hoC2S4QAvD_Bw E.

2. World Health Organization. COVID19 significantly impacts health services for noncommunicable diseases [Internet]. News. 2020 [cited $2021 \mathrm{Feb}$ 2]. Available from: https://www. who.int/news room/detail/01-06-2020-covid-19significantly-impacts-healthservices-for-noncommunicablediseases.

3. World Health Organization. Impact of COVID-19 on peoples livelihoods, their health and our food systems [Internet]. News. 2020 [cited 2021 Feb 2]. Available from: https://www.who.int/news/item/1310-2020-impact-of-covid-19-onpeoples-livelihoods-their-health-andour-food-systems.

4. Kaye AD, Okeagu CN, Pham AD, et al. Economic impact of COVID-19 pandemic on healthcare facilities and systems: International perspectives. Best Pract Res Clin Anaesthesiol. 2020.

5. World Health Organization. The effects of virus variants on COVID19 vaccines [Internet]. Newsroom. 2021 [cited 2021 Mar 2]. Available from: https://www.who.int/newsroom/feature-stories/detail/theeffects-of-virus-variants-on-covid19-vaccines.

6. World Health Organization. WHO lists additional COVID-19 vaccine for emergency use and issues interim policy recommendations. 2021 [cited 2021 June 22]. Available from: https://www.who.int/news/item/0705-2021-who-lists-additional-covid19-vaccine-for-emergency-use-andis s u e s-interi m-poli cyrecommendations.

7. World Health Organization (WHO). Coronavirus disease ( COVID- 19 ):
Vaccines [Internet]. Newsroom. 2021 [cited 2021 Feb 26]. Available from: https://www.who.int/newsroom/q-a-detail/coronavirus-disease$\left(\begin{array}{lllllllll}\mathrm{c} & \mathrm{o} & \mathrm{v} & \mathrm{i} & \mathrm{d} & - & 1 & 9\end{array}\right)$ vaccines? adgroupsurvey $=\% 7$ Badgro upsurvey\%7D\&gclid=CjwKCAiAm -2BBhANEiw.

8. Shekhar R, Sheikh AB, Upadhyay S, et al. COVID-19 Vaccine Acceptance among Health Care Workers in the United States. Vaccines 2021;9: 11933.

9. Gadoth A, Halbrook M, Martin-Blais $\mathrm{R}$, et al. Cross-sectional Assessment of COVID-19 Vaccine Acceptance Among Health Care Workers in Los Angeles. Ann Intern Med. 2021;27.

10. Lucia VC, Kelekar A, Afonso NM. COVID-19 vaccine hesitancy among medical students. J Public Health (Bangkok). 2020;fdaa230.

11. Manning M Lou, Gerolamo AM, Marino MA, Hanson-Zalot ME, Pogorzelska-Maziarz M. COVID-19 Vaccination Readiness among Nurse Faculty and Student Nurses. Nurs Outlook [Internet]. 2021;0:19. A vail a ble from : https://doi.org/10.1016/j.outlook.202 1.01.019.

12. World Health Organization. Coronavirus [Internet]. Health topics. 2021 [cited 2021 Feb 26]. p. 15 . A v a i l a b 1 e from : https://www.who.int/healthtopics/coronavirus\#tab=tab_1.

13. Erdem H, Lucey DR. Healthcare worker infections and deaths due to COVID-19: A survey from 37 nations and a call for WHO to post national data on their website. Int J Infect Dis [Internet]. 2021;102:23941. A vailable from : https://doi.org/10.1016/j.ijid.2020.10 .064 .

14. Bandyopadhyay S, Baticulon RE, 
Kadhum M, et al. Infection and mortality of healthcare workers worldwide from COVID-19: A systematic review. BMJ Glob Heal. 2020;5(12):e003097.

15. Shreffler J, Petrey J, Huecker M. The impact of COVID-19 on healthcare worker wellness: A scoping review. $\mathrm{W}$ e s t J E m e r g M e d. 2020;21(5):105966.

16. Santarone K, McKenney M, Elkbuli A. Preserving mental health and resilience in frontline healthcare workers during COVID-19. Am J Emerg Med. 2020;38(7):15301.

17. Nguyen LH, Drew DA, Graham MS, et al. Risk of COVID-19 among frontline health-care workers and the general community: a prospective cohort study. Lancet Public Heal. 2020;5(9):e47583.

18. Delgado D, Quintana FW, Perez G, et al. Personal safety during the covid19 pandemic: Realities and perspectives of healthcare workers in latin America. Int J Environ Res Public Health. 2020;17(8):2798805.

19. Prescott K, Baxter E, Lynch C, Jassal S, Bashir A, Gray J. COVID-19: how prepared are front-line healthcare workers in England? J Hosp Infect. 2020;105:1425.

20. Ogolodom M, Mbaba A, Alazigha N, et al. Knowledge, attitudes and fears of healthcare workers towards the coronavirus disease (COVID-19) pandemic in South-South, Nigeria. $\mathrm{H}$ e a 1 S c i J [ I n t e rn e t]. 2020;6(2):77383. Available from: http://search.proquest.com.ezproxy.li b.monash.edu.au/docview/10301357 29.

21. Patelarou E, Galanis P, Mechili EA, et al. Factors influencing nursing students intention to accept COVID19 vaccination A pooled analysis of seven countries. MedRxiv [Internet].
2021 ; Available from: https://doi.org/10.1101/2021.01.22.2 1250321.

22. Bhagavathula AS, Aldhaleei WA, Rahmani J, Mahabadi MA, Bandari DK. Knowledge and perceptions of COVID-19 among health care workers: Cross-sectional study. JMIR Public Heal Surveill. 2020;6(2):e19160.

23. Plateau State Government of Nigeria. Plateau State [Internet]. At a Glance. 2019 [cited 2021 Mar 5]. Available f $\quad r \quad 0 \quad$ m https://www.plateaustate.gov.ng/plat eau/at-a-glance.

24. University of Jos. Unijos at a glance [Internet]. About Unijos. 2021 [cited 2021 Mar 13]. Available from: https://www.unijos.edu.ng/unijos-ata-glance.

25. Jekel J, Katz D, Elmore J. Sample size determination and probability theory. In: Epidemiology, biostatistics and preventive medicine. 2nd ed. Philadelphia: W.B. Saunders; 2001.p. 1989. Saied SM,

26. Saied EM, Kabbash IA, Abdo SAE-F. Vaccine hesitancy: Beliefs and barriers associated with COVID-19 vaccination among Egyptian Medical Students. J Med Virol [Internet]. 2021; Available from: https://doi.org/10.1002/jmv.26910.

27. World Health Organization. Fighting misinformation in the time of COVID-19, one click at a time [Internet]. Newsroom. 2021 [cited 2021 May 7]. Available from: https://www. who.int/news room/feature-stories/detail/fightingmisinformation-in-the-time-ofcovid-19-one-click-at-a-time.

28. Adejumo PO, Moronkola OA, Okanlawon AF, et al. Knowledge , attitude and willingness of Nigerian nursing students to serve as 
volunteers in covid-19 pandemic. Int J Nurs Midwifery. 2021;13(1):110. Pandit SB,

29. Pandit RB. Knowledge, Attitude and Practices of Nursing Students towards COVID - 19: A Cross Sectional Study. Int J Heal Sci Res. 2021;11(1):2614.

30. Noreen K, Zil-E- Rubab, Umar M, Rehman R, Baig M, Baig F. Knowledge, attitudes, and practices against the growing threat of COVID19 among medical students of $\mathrm{P}$ a k i s tan. P L o S O n e. 2020;15(12):e0243696.

31. Alsoghair M, Almazyad M, Alburaykan T, et al. Medical students and COVID-19: Knowledge, preventive behaviors, and risk perception. Int $\mathrm{J}$ Environ Res Public Health. 2021;18(2):842.

32. Okoro J, Ekeroku A, Nweze B, et al. Attitude and preventive practices towards COVID-19 disease and the impact of awareness training on knowledge of the disease among correctional officers. Emerald Open Res. 2020;2:51.

33. Enabulele O, Esther A. The risk perception of covid-19 and practice of precautionary measures amongst healthcare workers in the national health insurance scheme clinic of a tertiary hospital in Nigeria. Pan Afr Med J. 2021;38(73).

34. Ferrer R, Klein WM. Risk perceptions and health behavior. Curr Opin Psychol. 2015;5:859.

35. Manning M Lou, Gerolamo AM, Marino MA, Hanson-zalot ME, Pogorzelska-maziarz M. COVID-19 vaccination readiness among nurse faculty and student nurses. Nurs O u t 1 o o k. 2021 ; S 0029 6554(21):000233.

36. Szmyd B, Bartoszek A, Karuga FF, Staniecka K, Błaszczyk M, Radek M. Medical students and sars-cov-2 vaccination: Attitude and behaviors. Vaccines. 2021;9(2):128.

37. Kaufman SB. Taking Sex Differences in Personality Seriously [Internet]. Vol. December, Scientific American. 2019 [cited 2021 May 12]. A va i a b l e from : https://blogs.scientificamerican.com/ beaut iful-minds/taking - sex differences-in-personality-seriously.

38. Mascarenhas AK, Lucia VC, Kelekar A, Afonso NM. Dental students attitudes and hesitancy toward COVID-19 vaccine. J Dent Educ [Internet]. 2021;(February):17. A va i a ble from : http://www.ncbi.nlm.nih.gov/pubme d/33913152. 